\title{
物語文における登場人物の感情理解を促進するイメージ図式
}

\author{
$\bigcirc$ 伊藤尚枝 \\ (恵泉女学園大学 人間社会学部) \\ キーワード : 物語理解, 登場人物の感情, イメージ図式
}

An image schema to promote a better understanding of emotions of characters in narrative

Hisae Ito

(Faculty of Human and Social Studies, Keisen University)

Key Words: Narrative Comprehension, Character's Emotion, Image Schema

目 的

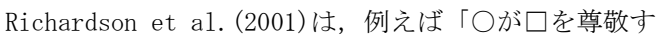
る」「○が口を軽荗する」という動詞文を使用して，読者が ○とロをどのような位置関係でイメージするか自由に描画さ せて調べた。すると, 上下方向の空間イメージを表象してい ることがわかった。そして，言語によるコミュニケーション が円滑に進むのは，このような空間のイメージ図式が話者間 で共通基盤になっているからかもしれないと指摘している。

物語を作者と読者のコミュニケーションと考えれば，人物 の気持ちを読み取っている読者ほど, 空間イメージを表象し ていると推測できる。本研究は, 登場人物の感情理解の違い に応じて, 動詞文の空間イメージに違いがあるかを調べる。

\section{方 法}

実験参加者 女子大生 42 名（19～22 歳）

呈示文「スチュワーデス志願」（1200 字程度）を一部改変 して使用した（女のレポート編集部編，2010，pp.44-45）。 あらすじを表 1 に示す。

$$
\text { 表 } 1 \text { 呈示文のあらすじ }
$$

1960年代、私は羽田空港の国際カウンターで、地上勤務

第 1 段落 職員として働いていた。その当時も、スチュワーデスは、 若い女性にとってあこがれの職業だった。

あの頃は、就職の情報がなかったので、春先になると、

第 2 段落 スチュワーデス希望の若い女性達が空港に現れた。

そして、情報を得ようとして、空港内をウロウロして、 働く人達をじっと見つめていた。

口の悪い先輩は、そんな彼女たちを「空港に来ても

第3 段落 意味がない」と相手にしない。あるとき、私は 1 人の 女性から質問された。私は誠意を持って彼女に応答した。

数年後、私は 1 人のスチュワーデスから声をかけられた。 第4段落 私に質問した彼女であった。彼女の颯爽とした姿を見て 胸が熱くなった。

手続き 呈示文を第 3 段落まで黙読してもらつたあと，描画 課題に答えてもらつた。課題では, まず, 図 1 を例示した。 そして，○だけを書き込んだマス目を呈示して，「若い女性 （○）が，“私’ ( $\triangle$ ）に質問する。」からイメージできる ○と $\triangle$ の位置を描画するように求めた。図 1 のマス目は, 平ら（2009）を参照にして作った。 続けて,「1人の若い女性が ‘私’ に声をかけた時，その女性は， どの程度不安な気持ちだったと 思いますか?」という質問に 答えてもらった。この質問には, 「少し不安 (1 点)」〜「とても 不安 (8 点)」までの 8 件法で 回答してもらった。最後に 第 4 段落まで黙読してもらった。

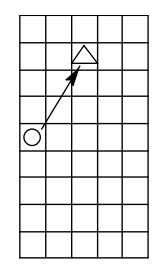

（例）○が $\triangle$ を尊敬する

図 1 描画課題の例題

\section{結 果}

1. 不安の程度で 2 群（低群・高群）を構成（質問項目） 女性の不安の程度を表寸得点順にならべて, 得点の低い9 名 （ $1 \sim 6$ 点）を低群とした。得点の高い 9 名（ $7 \sim 8$ 点）を 高群とした。残り 24 名は分析から除外した。2 群の平均值 と標準偏差を表 2 に示す。 2 群の平均值に有意な差が認めら れたので, 高群のほうが低群よりも, 若い女性の不安な気持 ちを理解していたといってもよいだろう。

\section{2. 上下方向の空間イメージの分析 (描画課題)}

$2 つ$ 群ごとに, ○から $\triangle$ をつな゙矢印の角度を測定した。 角度は, 水平方向を 0 度として, 垂直上下方向（90 度〜 -90 度）で数值化した。表 3 に低群と高群の角度の平均值 と標準偏差を示す。 2 群の平均值に有意な差が認められた。 高群のほうが, 私 $(\triangle)$ を若い女性 $(\bigcirc)$ よりも上方向に 描いて, 上下の位置関係を表象していたようである。 表 2 不安の得点の平均值と標準偏差

\begin{tabular}{cccc}
\hline $\begin{array}{c}\text { 高群 } \\
n=9\end{array}$ & $\begin{array}{c}\text { 低群 } \\
n=9\end{array}$ & $t$ 值 & 自由度 \\
\hline $\begin{array}{c}7.56 \\
(0.73)\end{array}$ & $\begin{array}{c}4.56 \\
(1.33)\end{array}$ & $5.93^{* *}$ & 16 \\
\hline & & & \\
\hline
\end{tabular}

（）内は標準偏差を表す。

表 3 描画の矢印の角度の平均值と標準偏差

\begin{tabular}{cccc}
\hline $\begin{array}{c}\text { 高群 } \\
n=9\end{array}$ & $\begin{array}{c}\text { 低群 } \\
n=9\end{array}$ & $t$ 值 & 自由度 \\
\hline $\begin{array}{c}48.89 \\
(19.17)\end{array}$ & $\begin{array}{c}18.89 \\
(14.53)\end{array}$ & $3.47^{* *}$ & 16 \\
\hline \multicolumn{4}{c}{$* p<.05}$,
\end{tabular}

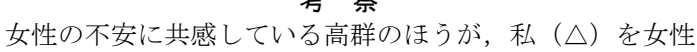
(○)よりも高い位置に表象していた。人物の気持ちを理解 している読者ほど, 私と女性の立場の強弱関係を上下の空間 イメージとして表象できていたと推測できる。

\section{引用文献}

Richardson, D. C., Spivey, M. J., Edelman, S., \& Naples, A. J. (2001). "Language is spatial” : Experimental evidence for image schemas of concrete and abstract verbs. Proceedings of the 23rd Annual Meeting of the Cognitive Science Society, 873-878.

平 知宏 - 中本 敬子 - 木戸口 英樹 - 木村 洋太 - 常深浩平 楠見 孝（2009）。具体文および抽象文を用いた行為・文 一致効果の実験的検証. 認知心理学研究, 7, 57-66. 